\title{
Divorce in Malaysia: Historical Trends and Contemporary Issues ${ }^{1}$
}

\author{
Gavin W. Jones ${ }^{\mathrm{a}}$
}

\begin{abstract}
Divorce rates in Malaysia have risen substantially in the first two decades of the 21 $2{ }^{\text {st }}$ century. The main upsurge was between 2007 and 2010, after which the rates levelled off. The Muslim divorce rate remains at a level more than double that of non-Muslims, though the trends in divorce have moved in the same direction for both groups. East Malaysia has its own patterns. Muslim divorce rates in Sabah are only half those in Peninsular Malaysia, as are non-Muslim divorce rates in both Sabah and Sarawak. Although information is not available for Malaysia about the proportion of Muslim divorces initiated by wives, for both Indonesia and Singapore, more than two thirds of Muslim divorces are initiated by the wife. Clearly, many similar forces are influencing divorce for both Muslims and non-Muslims in the predominantly urban populations of these three countries. "Modern divorce" is related to the pressures of urban living; pressures of balancing work responsibilities and household arrangements when both partners are working; decreasing tolerance for remaining in an unsatisfactory marriage; and increasing community acceptance of divorce in such circumstances. As similar pressures have been experienced by both Muslim and non-Muslim populations, the tendency for Muslim and non-Muslim divorce rates in Malaysia to move in parallel directions is not surprising.
\end{abstract}

Keywords: Divorce; Marriage; Muslim; Non-Muslim; Peninsular Malaysia; Sabah; Sarawak.

JEL Classification: J120, J100, J190

a College of Arts \& Social Sciences, Australian National University, Canberra ACT 0200, Australia.Email: Gavin.Jones@anu.edu.au, ORCID: 0000-0001-7114-5053 


\section{Introduction}

Divorce in Malaysia has an interesting history. It needs to be discussed separately for Malays, Chinese and Indians in Peninsular Malaysia, and for Muslim and non-Muslim Bumiputera and Chinese in East Malaysia, because historically, there have been sharp and fundamental differences in divorce rates between these groups. While 60 years ago and earlier, Muslims in Malaysia had far higher divorce rates than non-Muslims, at the present time these differences have narrowed considerably, though divorce rates for Muslims (mainly Malays) in Peninsular Malaysia are over twice as high as for non-Muslims (mostly Chinese and Indians), while in Sarawak, Muslim divorce rates are over three times as high as for non-Muslims, and in Sabah, about four times as high. ${ }^{2}$

The study of divorce in Malaysia is hindered by incomplete data. This will be evident from gaps in some of the analysis possible in this paper. Over time, though, the data situation has improved considerably, and time-series data are now available separately for the main ethnic groups for each state in Peninsular Malaysia, and separately for Muslims and non-Muslims in Sabah and Sarawak - a far remove from the situation prevailing four decades ago when the author was preparing his paper on Malay marriage and divorce in Peninsular Malaysia (Jones, 1981). Survey data to flesh out interpretation of the statistical series are now also more widely available.

There are three kinds of measures of divorce: (1) measures based on the current marital status of the population (specifically: the proportion of the total adult population who are currently divorced, or the proportion of the ever-married population who are currently divorced); (2) numbers of divorces registered in a given time period, which can be related to a given denominator - typically the total population (the crude divorce rate), or to the population aged $15+$ (the general divorce rate $)^{3}$, or to the currently married population in the year concerned ${ }^{4}$; and (3) cohort measures the outcomes of marriages entered into by members of different birth or marriage cohorts. Data are most readily available from censuses and surveys on the first, but it is difficult to interpret such data, because numerous factors can influence the current marital status (for example, particularly for the younger age groups, trends towards later age at marriage, for older age groups, trends in widowhood, and for all age groups, changes in desire and/ or opportunity to remarry after divorce). 
Despite the problems in interpreting trends in percentages currently divorced, the availability of a data series following trends in this measure over a period of four crucial decades of transition in Peninsular Malaysia's divorce situation is a good reason for presenting this information early in the present paper, before turning to more refined measures of the incidence of divorce, for which data are harder to come by. Figure 1, then, shows trends in the proportion of women in 10-year age groups from 20-29 to 50-59, who were currently divorced, from 1970 to 2010, and the more detailed Appendix Table 1 shows the same information for each 5 -year age group. Further detail for 2010 is provided in Appendix Table 2. ${ }^{5}$ There are wide differences between the ethnic groups.

For Malays, high divorce rates around the 1950s, 1960s and 1970s are reflected in high percentages of women currently divorced at ages 45 and above - in 1970, 1980 and 1991. Since then, the percentages currently divorced have declined. The only group of Malay women for which the proportion currently divorced exceeded $5 \%$ was women aged in their $50 \mathrm{~s}$ in 1980; given the very high rates of divorce prevailing before that time (to be discussed below), the figures suggest a high rate of re-marriage after divorce. For Chinese and Indians, percentages currently divorced are considerably lower than for Malays of all ages. For Chinese, there are no consistent time trends in percentages currently divorced, except for the most recent period (2000-2010), during which there has been a rise in percentages currently divorced for all age groups above 25. Indian women show generally higher proportions currently divorced than Chinese, and like Chinese, there is a clear increase in percentages currently divorced between 2000 and 2010 for all age groups above 25 .

\section{Divorce in the Last Half of the $\mathbf{2 0}^{\text {th }}$ Century}

Around the 1950s, the Malay population of Peninsular Malaysia had very high divorce rates, and the state of Kelantan had the doubtful distinction of having possibly the highest rates of divorce in the world. Why were divorce rates so high? Many factors contributed. While parent-arranged marriage at young ages was the norm, a key concern being to protect the reputation of the family by avoiding disasters such as pre-marital pregnancies, women were not forced to stay in an incompatible marriage. While divorce was not viewed favourably, divorces resulting from a daughter's reluctance or refusal 
to continue a marriage arranged by her parents did much less damage to a family's reputation than the scandal of the inability to control a daughter's sexuality, as evidenced by a pre-marital pregnancy.

Figure 1: Peninsular Malaysia: Trends in the Proportion of Women Currently Divorced, by Ethnic Group, 1970-2010

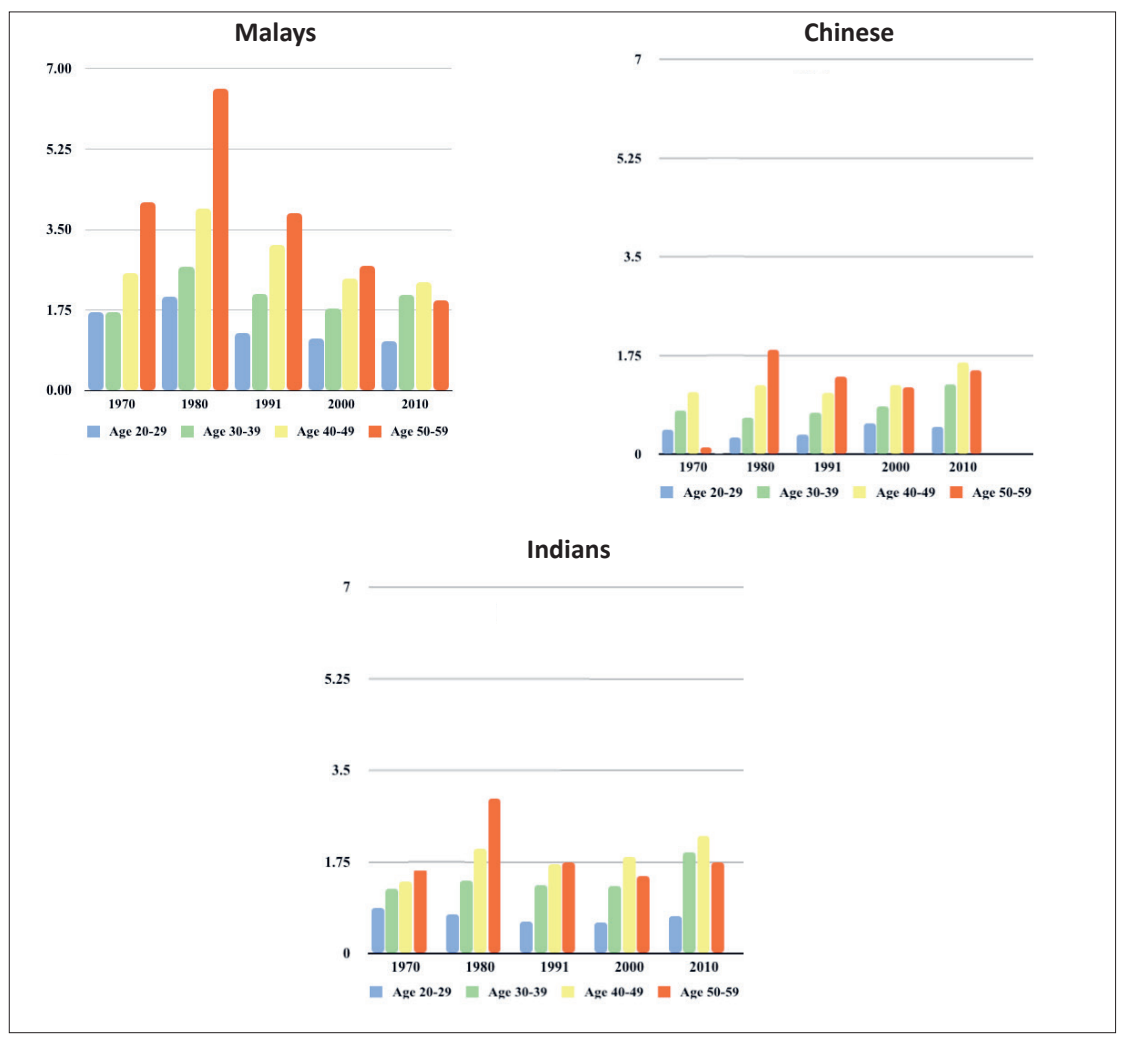

Source: Author's calculations from data sources on Malaysia's population and divorces: Population censuses, Department of Statistics, Malaysia, various years.

The context in Malay society, then, was a

... general tolerance of divorce in the society ...; legal ease of arranging a divorce; lack of strong economic deterrents; availability of practical and moral support for divorced women from her kin; the ease of remarriage, and flexible arrangements for the care of 
children after divorce. All of these factors operated in a context where young people were socially immature when they married, where polygyny was fairly common and wives often forestalled its occurrence by seeking a divorce, and where women had remarkable economic and social independence ... (Jones, 1997: 104).

For Chinese and Indian Malaysians, divorce was seen in a more disgraceful light. ${ }^{6}$ Partly as a consequence, divorce rates were far lower. Their crude divorce rate was around 0.02 per thousand population in the 1970s (Jones, 1980: 285) - less than one-hundredth of the Malay rate at that time.

During the latter part of the $20^{\text {th }}$ century, there were sharply divergent trends in divorce rates for Malays, on the one hand, and Chinese and Indians, on the other. Malay rates plummeted, and by the mid-1980s, were well below those in Western countries (Jones, 1994, Table 5.8; Tan and Jones, 1990). The decline in Malay divorce rates continued up to the end of the 20th century, but finally ended, around 2001, at a crude divorce rate of 1.09 per thousand. Chinese and Indian rates, on the other hand, rose to 0.2 per thousand by 2000 , roughly 10 times higher than in the 1970 s, but still less than one-fifth of the Malay rate.

The reason Malay divorce rates fell precipitously was more to do with social and economic changes than with legal changes. The rising age at marriage and increased self-choice of a spouse were major reasons, because of what they signified about the maturity of those marrying and their stronger motivation for making the marriage work. Other factors, particularly affecting divorces occurring after some years of marriage, included rising levels of living, which lessened poverty-related causes of divorce and increased the complexity of dealing with joint assets in a divorce situation; increasingly negative attitudes to divorce in the society, spearheaded by women's groups which emphasised the negative effects of divorce on women and children; and pressure on the government, especially from women's groups, to tighten enforcement of regulations relating to divorce. Divorce rates were already quite low when the Islamic Family Law Act of 1984 was enacted. The debates leading up to its enactment and the increasingly negative official and community attitudes being expressed at that time probably had as great or greater an influence on divorce trends as the laws themselves. ${ }^{7}$

During the period of very high Malay divorce rates (the 1950s to 1970s, 
and probably in the decades prior to 1950) in Peninsular Malaysia, there were very wide differentials in the Malay divorce rates between states. In 1965, for example, the general divorce rates for Malays in Kelantan and Terengganu were double the rate for the Malay population as a whole, and four or five times as high as in Selangor, Malacca and Johor. States such as Kedah, Perak and Pahang were in an intermediate situation.

The states with the highest divorce rates (for Malays) were those whose populations were poorest, most rural, and least educated, where age at marriage was lowest and marriages most strictly parent-arranged, where the rate of polygyny was highest, where changes wrought by British colonialism were least, where the laws on registration of talak left the most loopholes, and where the administration of these laws was loosest. (Jones, 1981: 263)

These differentials narrowed considerably later in the century; by 1985 , Terengganu had a divorce rate twice as high as Kelantan, and Kelantan's rate was barely any higher than that of Selangor and Johor (Jones, 1994, Table 5.8 and Figure 5.2).

What about divorce trends in East Malaysia? We know very little about this in earlier times. As a result, Sabah and Sarawak will not be covered in this discussion of divorce trends in the last half of the $20^{\text {th }}$ century.

\section{The $21^{\text {st }}$ Century Upsurge in Divorce}

Malaysia started out the 21st century with divorce rates at their historically lowest level, far lower than those in Western countries. Malaysia had a crude divorce rate of 1.0, whereas the European Union (EU) countries had a rate of 1.7, the US was higher at 4.0 and Russia was higher still at 4.3. The early years of the $21^{\text {st }}$ century witnessed very sharp changes in divorce rates in Malaysia. Figure 2 shows the trends in crude divorce rates and general divorce rates in Peninsular Malaysia from 2000 to 2019, separately for the Muslim and non-Muslim population. In the 2000-2010 decade, the rates for both Muslims and non-Muslims more or less doubled, and for both, the main upsurge was between 2007 and 2010. The rate then levelled off between 2010 and 2019, for both Muslims and non-Muslims. At present, the Muslim divorce rate remains at a level more than double that of non-Muslims. 
Figure 2: Peninsular Malaysia: Trends in Crude Divorce Rate and General Divorce Rate, Muslims and Non-Muslims, 2000-2019

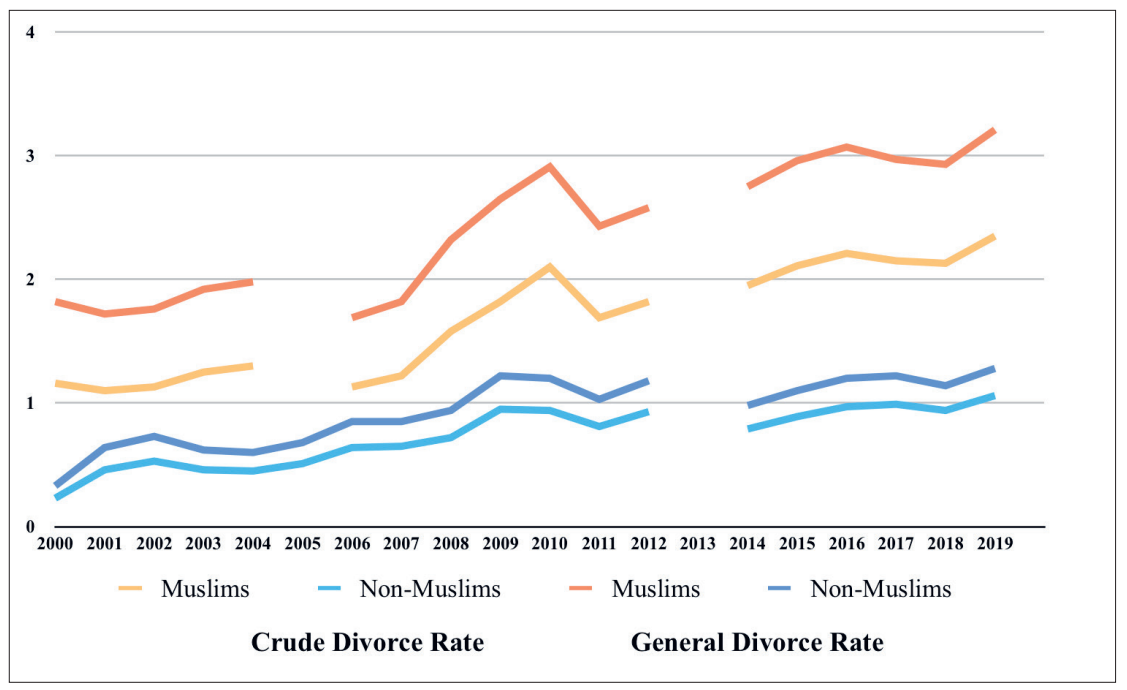

Source: Author's calculations from data sources on Malaysia's population and divorces: Population censuses, Department of Statistics, Malaysia, various years.

The differential between Muslim and non-Muslim divorce rates is wider when measured by the general divorce rate than by the crude divorce rate. This is because children are excluded from the denominator of the general divorce rate. Since children are not subject to divorce, it is better that they are not included in the denominator; this means that the general divorce rate gives a more realistic picture of the incidence and trends in divorce than the crude divorce rate. Since Muslim fertility rates in Peninsular Malaysia are much higher than non-Muslim fertility rates, there is a lower proportion of children in the non-Muslim population, and this is the reason for the wider Muslim-non-Muslim differential in general divorce rates than in crude divorce rates. In 2019, the crude divorce rate for Muslims was 2.2 times higher than that for non-Muslims, but the general divorce rate for Muslims was 2.5 times higher than for non-Muslims.

Table 1 shows the trends in key divorce rates from 2006 to 2018, for Malaysia as a whole, Peninsular Malaysia and Sabah and Sarawak. Unfortunately, data are not available for the East Malaysia states of Sabah and Sarawak back to 2000, and that is why the comparison begins in 2006 . 
Table 1: Malaysia: Trends in Divorce Rates for Muslim and Non-Muslim Population, 2000 to 2018

\begin{tabular}{lcccccc}
\hline & \multicolumn{2}{c}{ Number of divorces } & \multicolumn{2}{c}{ Crude divorce rate } & \multicolumn{2}{c}{ General divorce rate } \\
\cline { 2 - 7 } & Muslim & $\begin{array}{c}\text { Non- } \\
\text { Muslim }\end{array}$ & Muslim & $\begin{array}{c}\text { Non- } \\
\text { Muslim }\end{array}$ & Muslim & $\begin{array}{c}\text { Non- } \\
\text { Muslim }\end{array}$ \\
\hline MALAYSIA & & & & & & \\
2000 & 13,605 & $1,613^{*}$ & 1.0 & 0.2 & 1.5 & 0.2 \\
2006 & 17,458 & 5,480 & 1.1 & 0.5 & 1.7 & 0.7 \\
2010 & 32,701 & 8.561 & 1.9 & 0.8 & 2.8 & 1.1 \\
2018 & 40,269 & 10,087 & 2.0 & 0.8 & 2.6 & 1.0 \\
\hline Peninsular Malaysia & & & & & \\
2006 & 14,930 & 4,888 & 1.1 & 0.6 & 1.7 & 0.9 \\
2010 & 29,030 & 7,672 & 2.1 & 1.0 & 2.9 & 1.2 \\
2018 & 35,423 & 8,514 & 2.2 & 0.9 & 2.8 & 1.2 \\
\hline Sabah & & & & & & \\
2006 & 1,272 & 156 & 0.7 & 0.2 & 1.1 & 0.2 \\
2010 & 2,023 & 227 & 1.0 & 0.2 & 1.5 & 0.3 \\
2018 & 2,895 & 359 & 1.1 & 0.3 & 1.5 & 0.3 \\
\hline Sarawak & 1,256 & 436 & 1.7 & 0.3 & 2.5 & 0.4 \\
2006 & 1,648 & 662 & 2.1 & 0.4 & 3.0 & 0.5 \\
2010 & 1,951 & 1,214 & 2.2 & 0.6 & 2.8 & 0.8 \\
2018 & & & & & & \\
\hline
\end{tabular}

Notes: Crude divorce rate $=$ divorces per 1,000 population. General divorce rate $=$ divorces per 1,000 population age $15+{ }^{*}$ The number doubled in the following year -2001 .

Source: Author's calculations from data sources on Malaysia's population and divorces: Population censuses, Department of Statistics, Malaysia, various years.

As Peninsular Malaysia is by far the most populous component of Malaysia, it is not surprising that its divorce rates for Muslims and nonMuslims do not diverge very much from those for Malaysia as a whole. But there are some interesting differences in Sabah and Sarawak. While Muslim divorce rates in Sarawak closely mirror those in Peninsular Malaysia, Muslim divorce rates in Sabah are only half those in Peninsular Malaysia. ${ }^{8}$ Non-Muslim divorce rates in both Sabah and Sarawak (especially Sabah) are considerably lower than in Peninsular Malaysia. Between 2010 and 2018, divorce rates in Sabah were largely unchanged, but in Sarawak there was a 
slight decline for Muslims (according to the general divorce rate) and a slight increase for non-Muslims.

Trends for the main ethnic groups in Peninsular Malaysia - Malays, Chinese and Indians - are of considerable interest (see Table 2). In Peninsular Malaysia, the crude divorce rate for Malays climbed from its nadir of 1.09 per thousand in 2001 to 1.32 per thousand in 2005, and more rapidly to 2.16 per thousand in 2010 . Chinese and Indian rates, though much lower, continued their climb, reaching 0.2 per thousand in 2000 and increasing further to 0.45 per thousand in 2005 and more rapidly to 1.04 per thousand in 2010. It is noteworthy that in the years 2003-2010, Kelantan Malays, which used to have the highest divorce rates in the world, had lower divorce rates than Kuala Lumpur Malays. The former pattern of extremely high divorce rates in the highly rural East Coast states of Kelantan and Terengganu, much higher than in the more urbanised West Coast states of Selangor, Federal Territory of Kuala Lumpur, Melaka and Johor, has been entirely overturned in the present century.

Table 2: Crude Divorce Rate for Malays and Non-Malays, Peninsular Malaysia and Selected States, 2000-2010

\begin{tabular}{l|cccc|c}
\hline \multicolumn{5}{c}{ Year } & \multicolumn{3}{c}{ Malays } & \multicolumn{2}{c}{$\begin{array}{c}\text { Chinese and } \\
\text { Indians }\end{array}$} \\
\cline { 2 - 6 } & $\begin{array}{c}\text { Peninsular } \\
\text { Malaysia }\end{array}$ & Kelantan & Terengganu & $\begin{array}{c}\text { Kuala } \\
\text { Lumpur }\end{array}$ & $\begin{array}{c}\text { Peninsular } \\
\text { Malaysia }\end{array}$ \\
\hline 2000 & 1.15 & 1.47 & 1.18 & 0.91 & 0.21 \\
2001 & 1.09 & 1.64 & 1.20 & 1.28 & 0.44 \\
2002 & 1.13 & 1.16 & 0.91 & 1.38 & 0.50 \\
2003 & 1.22 & 1.48 & 0.98 & 1.50 & 0.41 \\
2004 & 1.26 & 1.47 & 1.26 & 2.14 & 0.42 \\
2005 & 1.32 & 1.40 & 1.35 & 2.01 & 0.45 \\
2006 & 1.37 & 1.45 & 2.44 & 1.85 & 0.69 \\
2007 & 1.31 & n.a. & 2.57 & 2.00 & 0.70 \\
2008 & 1.69 & 1.67 & 2.87 & 2.31 & 0.79 \\
2009 & 1.95 & 1.97 & 3.13 & 2.45 & 1.04 \\
2010 & 2.16 & 2.03 & 3.11 & 2.36 & 1.04 \\
\hline
\end{tabular}

Source: Tey (2011), Table 10.9, updated to 2010. 
This conclusion is confirmed by data for the Malay population of the various states of Peninsular Malaysia in 2000 and 2010 (see Table 3). Table 3 gives what is perhaps the best indicator of divorce rates if accurate data are available - the number of divorces per 1,000 married women. For Peninsular Malaysia as a whole, the Malay divorce rate doubled between 2000 and 2010. There were significant differences between states. In two states Kelantan and Perak - the rise in divorce rates was not very great. For all other states except Kedah, the increase in divorce rates over this period was very considerable. For Kedah, the accuracy of the data on registered divorces must be queried, because the 2010 number appears to be unrealistically low (only half of that in the tiny neighbouring state of Perlis). ${ }^{9}$

Table 3: Peninsular Malaysia's Malay Population: Divorces per 1,000 Married Women, 2000 and 2010

\begin{tabular}{|c|c|c|c|c|c|c|}
\hline \multirow[b]{2}{*}{ State } & \multicolumn{3}{|c|}{2000} & \multicolumn{3}{|c|}{2010} \\
\hline & $\begin{array}{c}\text { Number } \\
\text { of } \\
\text { married } \\
\text { Malay } \\
\text { women } \\
\end{array}$ & $\begin{array}{c}\text { Number } \\
\text { of } \\
\text { divorces } \\
\text { to Malay } \\
\text { women }\end{array}$ & $\begin{array}{l}\text { Divorce } \\
\text { rate* }\end{array}$ & $\begin{array}{c}\text { Number } \\
\text { of } \\
\text { married } \\
\text { Malay } \\
\text { women }\end{array}$ & $\begin{array}{c}\text { Number } \\
\text { of } \\
\text { divorces } \\
\text { to Malay } \\
\text { women }\end{array}$ & $\begin{array}{c}\text { Divorce } \\
\text { rate* }\end{array}$ \\
\hline Johor & 274,665 & 1,942 & 7.1 & 332,158 & 4,033 & 12.1 \\
\hline Kedah & 239,630 & 1,168 & 4.9 & 394,122 & 368 & 0.9 \\
\hline Kelantan & 211,791 & 1,784 & 8.4 & 268,622 & 2,900 & 10.8 \\
\hline Melaka & 70,967 & 394 & 5.6 & 99.855 & 1,402 & 14.0 \\
\hline $\begin{array}{l}\text { Negeri } \\
\text { Sembilan }\end{array}$ & 87,624 & 625 & 7.1 & 114,412 & 2,194 & 19.2 \\
\hline Pahang & 164,666 & 1,016 & 6.2 & 204,724 & 2,930 & 14.3 \\
\hline Perak & 196,244 & 1,234 & 6.3 & 251,474 & 1,951 & 7.8 \\
\hline Perlis & 35,322 & 188 & 5.3 & 39,562 & 629 & 15.9 \\
\hline Pulau Pinang & 99,270 & 647 & 6.5 & 128,399 & 1,795 & 14.0 \\
\hline Selangor & 375,372 & 2,075 & 5.5 & 574,829 & 6,169 & 10.7 \\
\hline Terengganu & 144,122 & 1,005 & 7.0 & 177,922 & 3,060 & 17.2 \\
\hline $\begin{array}{l}\text { FT Kuala } \\
\text { Lumpur }\end{array}$ & 96,755 & 499 & 5.2 & 133,482 & 1,602 & 12.0 \\
\hline $\begin{array}{l}\text { PENINSULAR } \\
\text { MALAYSIA }\end{array}$ & $1,996,428$ & 12,577 & 6.3 & $1,993,281$ & 24,632 & 12.4 \\
\hline
\end{tabular}

Note: *Number of divorces per 1000 married women.

Sources: Tey, 2009, Table 15; data from 2010 Population Census. 
Another measure that can be considered is the ratio of divorces to marriages occurring in the same year. This is in some ways inferior to, but in others, superior to, the general divorce rate or to the number of divorces per 1,000 married women. It is preferable in that (particularly for the Malay community), most divorces occur in the early years of marriage, and therefore it is somewhat unrealistic to relate divorces to the total stock of married women including the middle-aged and the elderly. On the other hand, only something like 10 or $15 \%$ of divorces occur in the first year of marriage $^{10}$, and therefore the appropriate denominator is broader than the population marrying in the same year as the divorce took place. However, particularly for a time series, the ratio of divorces to marriages in the same year is quite a good indicator of the incidence of divorce.

Table 4 shows trends in the ratio of divorces to marriages over the period from 2006 to 2019. The data are available for individual states. Some interesting facts emerge. First, consistent with the other sources of data showing rising divorce rates over the current century, both Muslim and non-Muslim divorce/marriage ratios roughly doubled between 2006-07 and 2017-19.

However, whereas the rise in general divorce rates levelled off over the second decade of the century (see Table 1), the ratio of divorces to marriages continued to rise over this period, for both Muslims and non-Muslims. The ratio of Muslim to non-Muslim divorce rates according to this measure started at 1.56 in the 2006-07 period, and finished at 1.53 in the 2017-19 period - almost the same, despite some ups and downs in the interim period.

Inter-state differences are interesting. For Malays, the highest divorce/ marriage ratio is in the states of Perlis, Pulau Pinang, Sarawak and Negeri Sembilan. Malacca was one of the highest in the earlier years, but not recently. There is less inter-state variation in the non-Muslim ratios; in the most recent period, the ratio is highest in Kuala Lumpur, and throughout the entire period, the lowest ratio has been in Sabah. ${ }^{11}$ 
Table 4: Divorces per 1,000 marriages, Muslim and Non-Muslim, States of Malaysia, 2006-2019

\section{A. MUSLIM}

\begin{tabular}{lccccc}
\hline & $\mathbf{2 0 0 6 - 2 0 0 7}$ & $\mathbf{2 0 0 8 - 2 0 1 0}$ & $\mathbf{2 0 1 1 - 2 0 1 2}$ & $\mathbf{2 0 1 4 - 2 0 1 6}$ & $\mathbf{2 0 1 7 - 2 0 1 9}$ \\
\hline MALAYSIA & $\mathbf{1 4 7}$ & $\mathbf{2 1 6}$ & $\mathbf{1 9 6}$ & $\mathbf{2 1 9}$ & $\mathbf{2 8 0}$ \\
Johor & 69 & 228 & 183 & 179 & 266 \\
Kedah & 57 & 47 & 195 & 155 & 228 \\
Kelantan & 36 & 173 & 153 & 203 & 244 \\
Melaka & 308 & 307 & 215 & 241 & 272 \\
N. Sembilan & 85 & 383 & 235 & 280 & 301 \\
Pahang & 149 & 131 & 194 & 206 & 251 \\
Perak & 93 & 127 & 136 & 157 & 273 \\
Perlis & 211 & 356 & 238 & 317 & 356 \\
P. Pinang & 375 & 411 & 242 & 264 & 323 \\
Sabah & 147 & 174 & 109 & 128 & 219 \\
Sarawak & 232 & 275 & 249 & 322 & 323 \\
Selangor & 268 & 338 & 267 & 353 & 347 \\
Terengganu & 274 & 291 & 217 & 229 & 251 \\
W.P. Kuala & 275 & 300 & 270 & 246 & 368 \\
Lumpur & & & & & \\
W.P. Labuan & n.a. & n.a. & 233 & 231 & 332 \\
Putrajaya & n.a. & n.a. & n.a. & 241 & 484 \\
\hline
\end{tabular}

\section{B. NON-MUSLIM}

\begin{tabular}{lccccc}
\hline State & $\mathbf{2 0 0 6 - 2 0 0 7}$ & $\mathbf{2 0 0 8 - 2 0 1 0}$ & $\mathbf{2 0 1 1 - 2 0 1 2}$ & $\mathbf{2 0 1 4 - 2 0 1 6}$ & $\mathbf{2 0 1 7 - 2 0 1 9}$ \\
\hline MALAYSIA & $\mathbf{9 4}$ & $\mathbf{1 2 3}$ & $\mathbf{1 2 5}$ & $\mathbf{1 5 4}$ & $\mathbf{1 8 3}$ \\
Johor & 106 & 158 & 141 & 193 & 213 \\
Kedah & 66 & 102 & 130 & 131 & 193 \\
Kelantan & 86 & 114 & 142 & 141 & 137 \\
Melaka & 65 & 124 & 155 & 228 & 219 \\
N. Sembilan & 88 & 113 & 147 & 193 & 215 \\
Pahang & 89 & 143 & 145 & 182 & 180 \\
Perak & 104 & 139 & 123 & 176 & 217 \\
Perlis & 62 & 118 & 122 & 201 & 217 \\
P. Pinang & 181 & 268 & 188 & 238 & 213 \\
Sabah & 52 & 67 & 83 & 98 & 113
\end{tabular}




\begin{tabular}{lccccc}
\hline State & 2006-2007 & $\mathbf{2 0 0 8 - 2 0 1 0}$ & $\mathbf{2 0 1 1 - 2 0 1 2}$ & $\mathbf{2 0 1 4 - 2 0 1 6}$ & $\mathbf{2 0 1 7 - 2 0 1 9}$ \\
\hline Sarawak & 76 & 80 & 98 & 137 & 146 \\
Selangor & 68 & 115 & 119 & 158 & 167 \\
Terengganu & 62 & 84 & 57 & 127 & 189 \\
W.P. Kuala & 141 & 205 & 206 & 181 & 236 \\
Lumpur & & & & & \\
W.P. Labuan & n.a. & n.a. & n.a. & n.a. & n.a. \\
Putrajaya & n.a. & n.a. & n.a. & n.a. & n.a. \\
\hline
\end{tabular}

Note: 2013 figures not available.

Source: Department of Statistics, various years. Buletin Perangkaan Sosial, Malaysia tables on number of registered Muslim and non-Muslim marriages and divorces, by state.

\section{Interval from Marriage to Divorce}

An important issue to investigate is the interval from marriage to divorce - what proportion of marriages are broken within different time intervals since marriage? Data on this matter were analysed by Tey (2011), based on data from the 2004 MPFS. He found that among the cohort married before $1980,10 \%$ of Malays had divorced within 5 years of marriage, compared with only $1 \%$ of Chinese. However, for later marriage cohorts, the proportion of Malays divorcing within 5 years was much lower, and for Chinese was somewhat higher, so that the differential between them had narrowed considerably for the 1985-89 marriage cohort (2.4\% for Malays and 1.5\% for Chinese).

Availability of data from the 2014 MPFS enables some updating of Muslim-non-Muslim differences in this respect. Table 5 presents the relevant data (for Muslims and non-Muslims, rather than for the separate ethnic groups), according to the years in which the marriages took place. There are a number of interesting features. First, as shown by the 2004 MPFS data, the per cent of Muslim marriages ending in divorce within 5 years is high for the cohort marrying before 1980. But the proportion fell off sharply for the marriage cohorts of the 1980s and 1990s, before rising again for cohorts married after the year 2000. Second, non-Muslim proportions divorcing in the first 5 years of marriage were more or less the same as for Muslims in the 1980s and 1990s marriage cohorts, and rose for marriages occurring in the later part of the 2000s decade, to a level above that for Muslims.

The percentages divorced within 10 and 15 years show much the same 
Muslim-non-Muslim differences, though of course the marriage cohort 20052009 is truncated, so it is not possible to tell whether the higher non-Muslim divorce percentages held at longer intervals since marriage.

Table 5: Malaysia: Proportion of Marriages Ended by Divorce within Different Time Intervals, Muslim and Non-Muslim populations, According to Year of Marriage.

\begin{tabular}{|c|c|c|c|c|c|c|c|c|}
\hline \multirow{2}{*}{$\begin{array}{c}\text { Year of } \\
\text { marriage }\end{array}$} & \multicolumn{2}{|c|}{$\begin{array}{c}\% \text { divorced } \\
\text { within } 5 \text { years }\end{array}$} & \multicolumn{2}{|c|}{$\begin{array}{c}\% \text { divorced } \\
\text { within } 10 \text { years }\end{array}$} & \multicolumn{2}{|c|}{$\begin{array}{c}\% \text { divorced } \\
\text { within } 15 \text { years }\end{array}$} & \multirow{2}{*}{$\begin{array}{c}\text { Number } \\
\text { of } \\
\text { Muslim } \\
\text { marriages }\end{array}$} & \multirow{2}{*}{$\begin{array}{c}\text { Number } \\
\text { of non- } \\
\text { Muslim } \\
\text { marriages }\end{array}$} \\
\hline & Muslim & $\begin{array}{c}\text { Non- } \\
\text { Muslim }\end{array}$ & Muslim & $\begin{array}{c}\text { Non- } \\
\text { Muslim }\end{array}$ & Muslim & $\begin{array}{c}\text { Non- } \\
\text { Muslim }\end{array}$ & & \\
\hline $\begin{array}{c}\text { Before } \\
1980\end{array}$ & 6.7 & 3.9 & 8.2 & 4.5 & 10.5 & 6.7 & 583 & 179 \\
\hline $\begin{array}{c}1980- \\
1989\end{array}$ & 3.0 & 3.1 & 5.3 & 4.4 & 7.4 & 5.9 & 1,275 & 523 \\
\hline $\begin{array}{c}1990- \\
1999\end{array}$ & 3.5 & 3.5 & 6.3 & 5.7 & 8.0 & 7.4 & 1,555 & 634 \\
\hline $\begin{array}{l}2000- \\
2004\end{array}$ & 4.9 & 3.1 & 8.8 & 9.0 & $*$ & $*$ & 692 & 255 \\
\hline $\begin{array}{l}2005- \\
2009\end{array}$ & 4.8 & 5.4 & $*$ & $*$ & $*$ & $*$ & 751 & 241 \\
\hline
\end{tabular}

Note: *Overlap between length of marriage and interval before divorce.

Source: based on unpublished data from 2014 MPFS.

The most notable feature of the 2014 MPFS data is the higher proportion of non-Muslim marriages ending in divorce within 5 years of marriage than was shown for the same marriage cohorts by the 2004 MPFS data. The comparison is not exact - Chinese and Indians in the earlier survey are being compared with non-Muslims in the 2014 survey. The 2014 survey also shows a rise in the proportion of non-Muslim marriages ending in divorce within 5 years for the most recent marriage cohort - the 2005-2009 cohort. Too much should not be made of these findings, given the relatively small sample for non-Muslims and the lack of exact consistency between the groups being compared.

\section{Causes of Divorce}

What are the main driving forces of divorce? While there is information on this from survey and other sources, most of it is of little value in understanding the causes of divorce. Typically, in such data, only a few 
possible reasons are allowed. For example, in one study, divorces among Malays in Perlis are categorised according to three causes: "incompatible", "irresponsible" and "spouses' attitude" (Norizan et al., 2017: 274). The Malaysian Population and Family Survey 2014 does give some more detailed information on reasons for divorce. They are summarised in Table 6. Such lists of reasons (only one given in each case) can tell us little about the causes of divorce, which are typically complex and interactive. One point to be made, however, is that the predominance of "incompatibility or irreconcilable differences" as the most important reason cited by both sexes strongly suggests an unwillingness to tolerate a bad marriage in a way that was much less the case as recently as 20 years ago.

Table 6: Malaysia: Reasons for Divorce/Separation (first marriage)

\begin{tabular}{lcc}
\hline & Males & Females \\
\hline Incompatibility or irreconcilable differences & 56.2 & 38.0 \\
Spousal infidelity & 11.8 & 20.5 \\
Irresponsible spouse & - & 15.2 \\
In-laws interference & 10.0 & 6.0 \\
Refuse to accept polygamy & - & 2.8 \\
Financial problems & - & 4.7 \\
Spouse's involvement in substance abuse & - & 2.4 \\
Others & $22.0^{*}$ & $10.4^{* *}$ \\
\hline TOTAL & $\mathbf{1 0 0}$ & $\mathbf{1 0 0}$ \\
\hline
\end{tabular}

Notes: *Includes financial problems, irresponsible spouse, childlessness, spouse's health problems, spouse's involvement in criminal cases and others. ${ }^{* *}$ Includes domestic abuse, childlessness, spouse's gambling addiction, spouse's health problems, spouse's involvement in criminal cases and others.

Source: National Population and Family Development Board (2016): 24.

\section{Seeking Explanations}

It was noted earlier that divorce rates in Malaysia at the turn of the $21^{\text {st }}$ century were well below those of Western countries. While rates in Malaysia have trended upwards since then, and this mirrors upward trends in divorce rates in EU countries (a slight upward trend in the crude divorce rate from 1.7 in 2000 to 2.0 in 2017), the rate in the US has trended downwards over 
the same period - from 4.0 in 2000 to 2.9 in 2017. In Western countries, interpretation of trends in divorce rates is complicated by the high proportion of cohabiting relationships in many countries, because the ending of a cohabiting relationship is not marked by an official divorce.

How does the upward trend in divorce rates for all ethnic groups in Malaysia over the first two decades of the $21^{\text {st }}$ century compare with trends in other parts of Southeast Asia? This is not easy to assess, given lack of good data for Thailand, and the inability of people to divorce in the Philippines. Other Southeast Asian countries provide good data for comparison, however. Given the continuing wide differences in divorce rates between Muslims and non-Muslims in Malaysia, comparisons ideally need to be made between the Muslim population of Malaysia and that of Indonesia and Singapore, and between the non-Muslim population of Malaysia and that of neighbouring Singapore, Cambodia and Vietnam.

\subsection{Muslim divorce rates in Malaysia and elsewhere in Southeast Asia}

Figure 3 gives some comparisons of trends in general divorce rates for Muslim populations of Peninsular Malaysia, Indonesia and Singapore since 1950. In all cases, there were very sharp declines over the 1950s and 1960s, continuing up to the 1990s in the cases of Indonesia and Peninsular Malaysia.

Figure 3: General Divorce Rates for Malays in Peninsular Malaysia, Indonesian Muslims and Singapore Muslims, 1950-2015

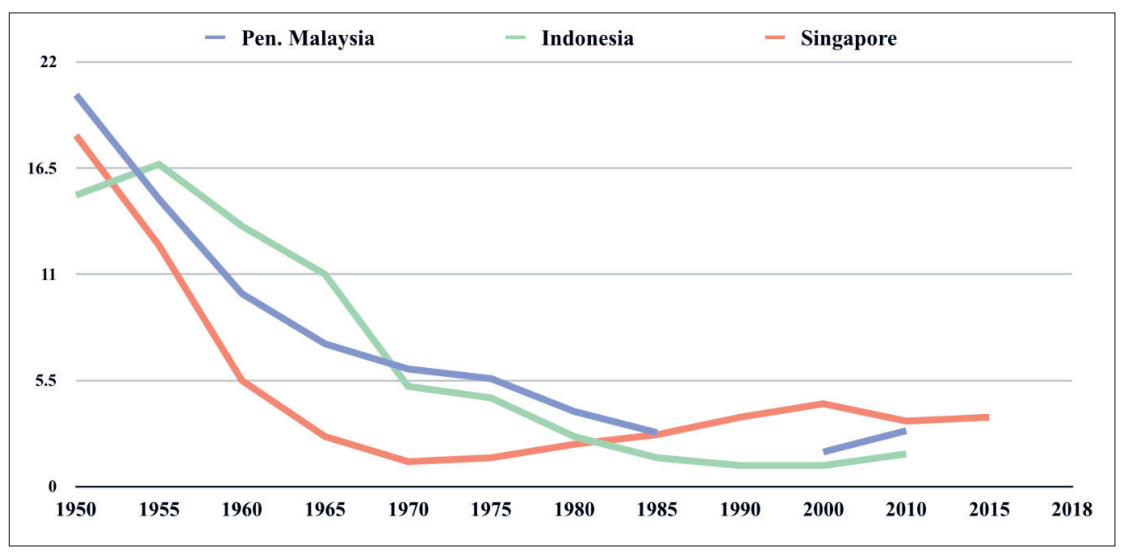

Note: Figures for 2000, 2010 and 2018 are for Muslims, not just Malays. Source: Jones (1994), Table 5.8; Table 2 above. 
In Indonesia, divorce rates began to rise again in the late 1990s (Cammack and Heaton, 2001). Among Singapore Malays, the rise in divorce rates began earlier (in the 1980s) and accelerated in the late 1990s and the early years of the $20^{\text {th }}$ century (Dommaraju and Jones, 2011, Figure 3b). This probably reflects the earlier, and greater strength of, forces making for higher divorce rates in highly urbanised and prosperous Singapore than in Malaysia and Indonesia. However, since the early years of the 21st century, Muslim divorce rates in Singapore have actually declined, the crude divorce rate falling from 2.8 in 2000 to 2.3 in 2010, and remaining at that level up to 2018. A range of Muslim Marriage Preparation courses have long been offered by the Singapore Ministry of Social and Family Development, Muslim organisations and private educational groups, and these may have had an impact on lowering the divorce rate in the Muslim community to a level not much different from that for non-Muslims (Mohamad and Suratman, 2016).

As noted earlier, in Malaysia, non-Muslim divorce rates rose sharply between 2000 and 2010, but levelled off after that. By comparison, in Singapore (after rising sharply between 1980 and 1990), non-Muslim divorce rates have not risen much since 1990, and have levelled off and barely changed at all since 2003 (Department of Statistics 2018, Table A2.1). The crude divorce rate is currently around 1.8 .

Studies have shown that in the United States (US), Europe and Australia, the majority of divorces are initiated by the wife (Rosenfeld, 2018; Kalmijn and Poortman, 2006). In the US, women initiated 69\% of all divorces (Rosenfeld, 2018). The same is true of Muslim divorces; although unfortunately, data are not available about the per cent of Muslim divorces in Malaysia that are initiated by wives, in Indonesia and Singapore the proportion is quite high. In the Islamic courts of Indonesia, the per cent of divorces initiated by wives rose from $58 \%$ in 2001 to $66 \%$ in 2009 (Cammack and Heaton, 2011: Table 3). By 2017, the per cent of divorces initiated by wives (cerai gugat) had risen to $73 \%$ (based on data in Rinaldo, Nisa and Nurmila, 2010: 3). In Singapore, for Muslim divorces in 2018, divorces filed by the wife made up $70.5 \%$, even higher than the proportion in 2008 (67.7\%) (Department of Statistics, 2018: 18).

What is clear is that in Singapore a much higher proportion of Muslim divorces occur during the first 5 years of marriage (30\%) than is the case for non-Muslim marriages (16\%). ${ }^{12}$ Unfortunately, comparable data for Malaysia are not available. 


\subsection{Non-Muslim divorce trends in Malaysia and elsewhere in SE Asia}

Figure 4 compares available data on trends in crude divorce rates for non-Muslim populations of Southeast Asia. For Singapore, the figures are actually for the whole population, including Muslims, but as Muslims make up only $15 \%$ of the total population, the rates in Figure 4 can be taken to roughly apply to the non-Muslim population.

Figure 4: Trends in Crude Divorce Rates, Thailand, Singapore, Vietnam and Peninsular Malaysia (Chinese and Indians)

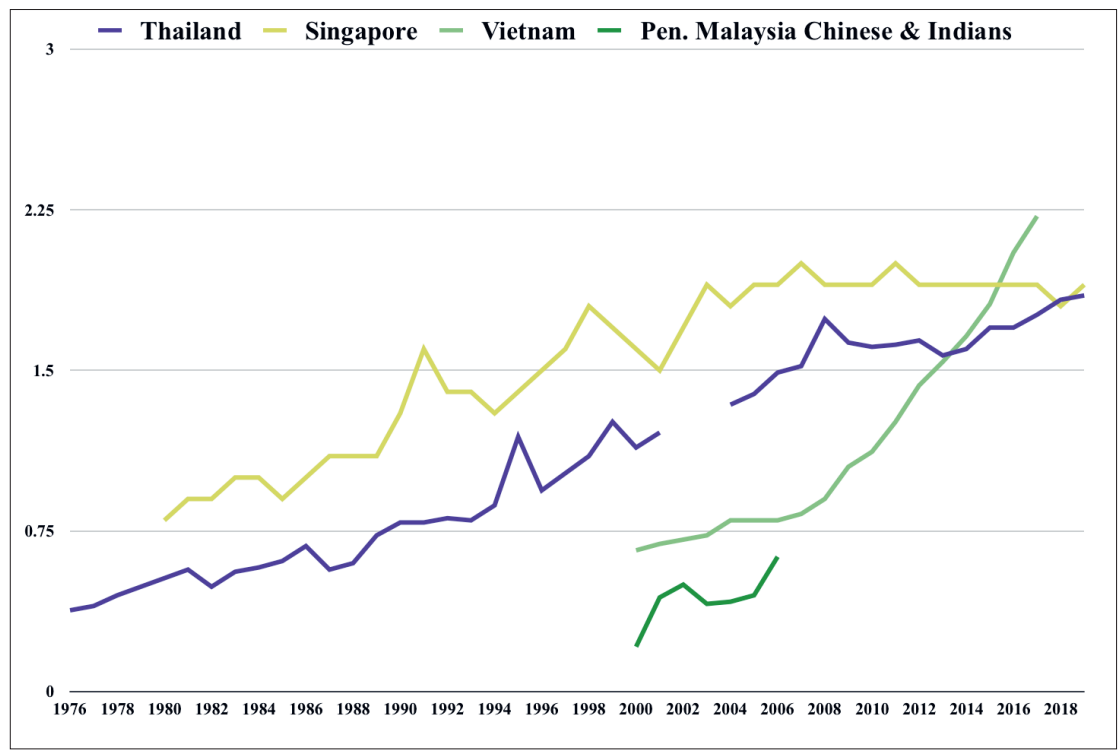

Sources: Dommaraju and Jones (2011), figure 2, updated from Department of Statistics, Singapore, 2019; United Nations Demographic Yearbook (2019), Table 24; and Thi (2021).

As noted earlier, in Malaysia, non-Muslim divorce rates rose sharply between 2000 and 2010, but levelled off after that. By comparison, in Singapore (after rising sharply between 1980 and 1990), non-Muslim divorce rates have not risen much since 1990, and have levelled off and barely changed at all since 2003 (Department of Statistics 2018, Table A2.1). The crude divorce rate is currently around 1.8 . 
Thailand has seen a steady increase in divorce rates since the 1980s, and by 2018 , its crude divorce rate had reached that of Singapore (see Figure 4). In Cambodia, there is evidence that the proportion of marriages ending in divorce has been increasing for more recent marriage cohorts. But the incidence of divorce, even for the most recent cohorts, remains quite low (Heuveline and Nakphong, 2020). Similarly, in Vietnam the crude divorce rate remains extremely low -0.4 per 1,000 in 2015 .

\section{Conclusions}

Over the second half of the $20^{\text {th }}$ century, Malay divorce rates in Peninsular Malaysia plummeted from spectacularly high levels to levels well below those in Western countries. At the turn of the $21^{\text {st }}$ century, these divorce rates were at the lowest level they had ever reached in the previous 100 years, and probably well before that.

In the present century, trends in Muslim divorce rates have differed across Southeast Asia. In Indonesia, the rate rose rapidly from 2000 to 2010, and then continued to rise substantially. In Malaysia, a similar early20th century rise was followed by a levelling off. In Singapore (after rising rapidly in the last 3 decades of the 20th century), Muslim divorce rates have been declining since 2000. How to explain these differences?

In Singapore, Muslims were subject to modernising forces and the pressures of living in a large city well before this was the case in Malaysia or Indonesia. So the considerably earlier rise in divorce rates in Singapore is not surprising. But more recently, in all three countries the Muslim population is living in an increasingly urban environment (in Indonesia, about 50\% urban, in Malaysia, $76 \%$ urban $^{13}$ and in Singapore, totally urban), with rising levels of female education and labour force participation. Thus, notwithstanding considerable cultural differences, it is hardly surprising if Muslim divorce patterns are coming to resemble more closely those for non-Muslims. But even so, the outcomes on Muslim divorce rates in the three countries are clearly different.

One possibly relevant point is that Muslims are the majority of the population in Indonesia and Malaysia, and hold great political power. This is not the case in Singapore, where the Malay population is a small minority, lower on the socio-economic scale and has limited political influence. But translating these different broader socio-political contexts into implications 
for family life and divorce trends presents great challenges.

As well as understanding differences in Muslim divorce trends in Malaysia and other parts of Southeast Asia, it is important to understand the different trends for Muslims and non-Muslims in Malaysia. Over the first decade of the present century, divorce rates doubled for Muslims, and rose even faster for non-Muslims. Then for both groups, divorce rates levelled off in the second decade of the century. The rise can readily be explained; the levelling off, though, leaves many questions unanswered.

What is clear is that, while religious-cultural influences on divorce are certainly different, many similar forces are influencing divorce rates for both Muslims and non-Muslims. First of all, with the postponement of marriages to a more mature age, and perhaps increasing care in assessing potential marriage partners, the likelihood of incompatibility as a cause of divorce is probably decreasing, though changing circumstances can introduce elements of incompatibility that were not predictable.

All communities in an increasingly urbanised Malaysia are experiencing what might be referred to as "modern divorce", related to the pressures of urban living; pressures of balancing work responsibilities and household arrangements when both partners are working; decreasing tolerance for remaining in an unsatisfactory marriage; and increasing community acceptance of divorce in such circumstances. Women are more financially independent than before, enabling them to contemplate the option of leaving an unsatisfactory marriage that was frequently not available to their mothers or grandmothers.

Perhaps the most important factors in explaining variations in divorce over time and between societies are the degree of stigmatisation of divorce, and the economic consequences of divorce for women. In traditional Malay/ Indonesian societies, divorce was high because there was little stigmatisation of divorce and divorce did not prevent women from surviving economically. The reverse was true in Chinese and South Asian societies and in the Chinese and South Asian immigrant communities in Malaysia. Over time, divorce became stigmatised in the Malay community, and this was a major factor in the precipitous decline in Malay divorce rates in the latter part of the $20^{\text {th }}$ century. On the other hand, a gradual erosion of the stigmatisation of divorce in the Chinese and Indian communities in Malaysia, and more recently probably in the Malay community as well, and the ability of educated working women to survive economically, was undoubtedly an 
important reason for the rise in divorce rates in these communities in more recent times. The rise of "modern divorce" in Malaysia in the 21st century has seen parallel trends in divorce rates for the Malay and non-Malay communities, with many of the same factors influencing both groups.

Many mysteries remain. For example, why did Malay divorce rates decline so steeply by the mid-1980s in Kelantan, falling to levels equal to those in the rest of Peninsular Malaysia, and by 2010 even below those in the more economically developed west coast states (see Table 3), despite the persistence in Kelantan of many of the factors making for high divorce rates, cited earlier in this paper? Understanding the reasons for such dramatic changes requires more careful delving into the administration and recording of Muslim divorces in the states of Malaysia, and more intensive sociological studies of the strains on marriages (see, for example, Mohamad and Shuib, 2011), and community attitudes to divorce.

\section{Acknowledgement}

The authors would like to thank the Department of Statistics, Malaysia and the National Population and Family Development Board, Malaysia for permission to use the data for this analysis.

\section{Funding}

This work was supported by the National Population and Family Development Board, Malaysia (Grant No.: GA025-2021).

\section{Notes}

1 The author wishes to thank Tey Nai Peng for considerable assistance in locating relevant data.

2 In both Sarawak and Sabah, Muslims are mostly Bumiputera, while non-Muslims are mostly Bumiputera and Chinese. Unlike in Peninsular Malaysia, then, in Sabah and Sarawak the term Bumiputera does not signify anything about religious belief.

3 The general divorce rate is a better indicator than the crude divorce rate because it eliminates children (who are not at risk of divorce) from the denominator. 
4 In Singapore, the Department of Statistics refers to this measure as the general divorce rate, unlike the definition of general divorce rate used in this paper.

5 Appendix Table 2 shows, for Malaysia and Peninsular Malaysia, the percentage of Muslim and non-Muslim women currently divorced in 2010.

6 One study conducted in 1981-82 illustrates this. A total of 2310 ever married women, from different states in Peninsular Malaysia (1388 of them Malay and the remainder Chinese and Indian) and their husbands, if present, were asked to choose a pre-coded answer to a question about their view of divorce. Among respondents as a whole, $71 \%$ of female respondents chose "not good, but at times have to take such a step". Another 21\% chose "disgraceful" - 15\% of Malays, 21\% of Chinese and $53 \%$ of Indians. The responses of husbands differed only slightly from those of wives (Tan and Jones, 1990, Table 10).

7 For a more detailed discussion, see Jones, 1997; Hirschman and Teerawichitchainan, 2003.

8 Perhaps this could result partly from a less complete recording of Muslim divorces in Sabah, given the large immigrant population, including undocumented migrants, but this is only speculation.

9 This raises an important issue. The Muslim divorce statistics for a number of states (notably Johor, Kedah, Kelantan, Negeri Sembilan, Pahang and Perlis) show enormous year-to-year fluctuations in the 2006-2010 period, suggesting the possibility of inaccurate recording and/or delayed registration. There is an urgent need for a careful evaluation of the procedures followed in each state in recording divorces, forwarding information to the relevant authorities, and making this information publicly available. At present, it is impossible to be fully confident about the quality of the Muslim divorce data.

${ }^{10}$ In Singapore, 30\% of Muslim divorces occur in the first 5 years of marriage, but only $18 \%$ of non-Muslim marriages (Department of Statistics, 2019: 16).

11 For more detail about divorce trends in Sabah, see Tey, forthcoming. 
12 These figures are for 2018. 10 years earlier - in 2008 - the Muslimnon Muslim difference was greater $-32 \%$ and $13 \%$ respectively. See Department of Statistics, 2018, Figure 2.6.

13 Though the proportion of the Muslim population living in urban areas is somewhat lower.

\section{Appendix}

Appendix Table 1: Peninsular Malaysia: Divorced Women as Percentage of Ever Married Women by Ethnic Group and Age Group, 1970-2010

\begin{tabular}{|c|c|c|c|c|c|}
\hline Ethnicity/Age & 1970 & 1980 & 1991 & 2000 & 2010 \\
\hline \multicolumn{6}{|c|}{ All ethnic groups } \\
\hline $20-24$ & 1.27 & 1.32 & 1.17 & 1.13 & 0.84 \\
\hline $25-29$ & 1.19 & 1.40 & 1.19 & 1.06 & 1.13 \\
\hline $30-34$ & 1.23 & 1.69 & 1.55 & 1.38 & 1.68 \\
\hline $35-39$ & 1.43 & 1.98 & 1.85 & 1.69 & 2.06 \\
\hline $40-44$ & 1.74 & 2.60 & 2.20 & 1.99 & 2.15 \\
\hline $45-49$ & 2.20 & 3.06 & 2.48 & 2.07 & 2.21 \\
\hline $50-54$ & 2.59 & 4.16 & 2.74 & 2.13 & 2.02 \\
\hline $55-59$ & 2.84 & 5.28 & 2.75 & 2.08 & 1.69 \\
\hline \multicolumn{6}{|l|}{ Malays } \\
\hline $20-24$ & 1.76 & 1.98 & 1.16 & 1.11 & 0.96 \\
\hline $25-29$ & 1.65 & 2.08 & 1.34 & 1.16 & 1.20 \\
\hline $30-34$ & 1.57 & 2.54 & 1.88 & 1.57 & 1.85 \\
\hline $35-39$ & 1.83 & 2.87 & 2.30 & 1.98 & 2.28 \\
\hline $40-44$ & 2.25 & 3.59 & 2.92 & 2.36 & 2.32 \\
\hline $45-49$ & 2.87 & 4.31 & 3.39 & 2.52 & 2.39 \\
\hline $50-54$ & 3.67 & 5.77 & 3.72 & 2.73 & 2.14 \\
\hline $55-59$ & 4.51 & 7.36 & 3.99 & 2.68 & 1.80 \\
\hline \multicolumn{6}{|l|}{ Chinese } \\
\hline $20-24$ & 0.38 & 0.24 & 0.32 & 0.58 & 0.34 \\
\hline $25-29$ & 0.49 & 0.35 & 0.37 & 0.52 & 0.63 \\
\hline $30-34$ & 0.68 & 0.54 & 0.62 & 0.73 & 1.02 \\
\hline $35-39$ & 0.86 & 0.76 & 0.86 & 0.97 & 1.45 \\
\hline $40-44$ & 1.00 & 1.09 & 1.02 & 1.21 & 1.56 \\
\hline
\end{tabular}




\begin{tabular}{cccccc}
\hline Ethnicity/Age & $\mathbf{1 9 7 0}$ & $\mathbf{1 9 8 0}$ & $\mathbf{1 9 9 1}$ & $\mathbf{2 0 0 0}$ & $\mathbf{2 0 1 0}$ \\
\hline $45-49$ & 1.20 & 1.35 & 1.15 & 1.24 & 1.69 \\
$50-54$ & 1.16 & 1.64 & 1.38 & 1.20 & 1.63 \\
$55-59$ & 1.19 & 2.05 & 1.35 & 1.18 & 1.35 \\
\hline Indian & & & & & \\
$20-24$ & 0.81 & 0.66 & 0.54 & 0.50 & 0.52 \\
$25-29$ & 0.95 & 0.83 & 0.68 & 0.68 & 0.90 \\
$30-34$ & 1.19 & 1.20 & 1.13 & 1.13 & 1.77 \\
$35-39$ & 1.26 & 1.60 & 1.49 & 1.44 & 2.09 \\
$40-44$ & 1.27 & 1.81 & 1.68 & 1.87 & 2.28 \\
$45-49$ & 1.49 & 2.18 & 1.71 & 1.82 & 2.20 \\
$50-54$ & 1.59 & 2.75 & 1.77 & 1.66 & 1.94 \\
$55-59$ & 1.65 & 3.18 & 1.72 & 1.32 & 1.53 \\
\hline
\end{tabular}

Source: Tey (2009), updated with 2010 Census data.

Appendix Table 2: Malaysia, Peninsular Malaysia, Sabah and Sarawak, 2010:

Percentage of Women Currently Divorced, by Age group, Muslim and Non-Muslim

\begin{tabular}{lcccccccc}
\hline \multirow{2}{*}{$\begin{array}{c}\text { Age } \\
\text { group }\end{array}$} & \multicolumn{2}{c}{ Malaysia } & \multicolumn{2}{c}{$\begin{array}{c}\text { Peninsular } \\
\text { Malaysia }\end{array}$} & \multicolumn{2}{c}{ Sabah } & \multicolumn{2}{c}{ Sarawak } \\
\cline { 2 - 8 } & Muslim & $\begin{array}{c}\text { Non- } \\
\text { Muslim }\end{array}$ & Muslim & $\begin{array}{c}\text { Non- } \\
\text { Muslim }\end{array}$ & Muslim & $\begin{array}{c}\text { Non- } \\
\text { Muslim }\end{array}$ & Muslim & $\begin{array}{c}\text { Non- } \\
\text { Muslim }\end{array}$ \\
\hline $15-19$ & 0.0 & 0.0 & 0.0 & 0.0 & 0.1 & 0.1 & 0.0 & 0.1 \\
$20-24$ & 0.3 & 0.1 & 0.2 & 0.1 & 0.2 & 0.1 & 1.0 & 0.2 \\
$25-29$ & 0.7 & 0.4 & 0.6 & 0.4 & 0.8 & 0.1 & 0.9 & 1.0 \\
$30-34$ & 1.4 & 0.7 & 1.3 & 0.6 & 1.9 & 0.9 & 2.3 & 1.5 \\
$35-39$ & 2.0 & 1.4 & 2.0 & 1.4 & 1.5 & 1.7 & 2.0 & 1.2 \\
$40-44$ & 2.0 & 1.2 & 1.9 & 1.0 & 2.0 & 2.5 & 3.3 & 1.3 \\
$45-49$ & 2.0 & 1.2 & 2.0 & 1.2 & 1.9 & 1.8 & 3.6 & 1.2 \\
$50-54$ & 1.7 & 1.2 & 1.6 & 1.2 & 1.7 & 1.7 & 2.4 & 0.8 \\
$55-59$ & 1.5 & 1.4 & 1.5 & 1.2 & 2.1 & 1.2 & 1.1 & 2.3 \\
$60-64$ & 1.2 & 0.6 & 1.2 & 0.6 & 1.0 & 0.5 & 2.8 & 0.4 \\
$65-69$ & 0.8 & 0.5 & 0.9 & 0.6 & 0.6 & 0.5 & 0.0 & 0.3 \\
$70-74$ & 0.7 & 0.3 & 0.7 & 0.1 & 0.0 & 1.5 & 0.0 & 0.8 \\
$75+$ & 0.6 & 0.3 & 0.6 & 0.7 & 0.0 & 0.9 & 0.0 & 0.9 \\
All ages & 1.1 & 0.7 & 1.1 & 0.7 & 1.0 & 0.9 & 1.6 & 0.9 \\
$15+$ & & & & & & & & \\
\hline
\end{tabular}

Source: 2010 Population Census data supplied by Tey Nai Peng. 


\section{References}

Cammack, M., \& Heaton, T. (2011). Explaining the recent upturn in divorce in Indonesia: developmental idealism and the effect of political change. Asian Journal of Social Science, 39(6), 776-796. (https://www.jstor.org/ stable/43498088)

Department of Statistics Malaysia. (various years). Social Statistics Bulletin, Malaysia. Putrajaya: Department of Statistics.

Department of Statistics. (2018). Statistics on Marriages and Divorces 2018. Singapore: Department of Statistics.

Department of Statistics. (2019). Statistics on Marriages and Divorces 2019. Singapore: Department of Statistics.

Dommaraju, P., \& Jones, G. (2011). Divorce tends in Asia. Asian Journal of Social Science, 39(6), 725-750. (DOI: 10.1163/156853111X619201)

Heuveline, P., \& Michelle K.N. (2020). Contemporary marriage in Cambodia. Paper presented at Conference on Emerging Dimensions of Marriage in Asia, Asia Research Institute, National University of Singapore, 19-20 November.

Hirschman, C., \& Bussarawan, T. (2003). Cultural and socioeconomic influences on divorce during modernization: Southeast Asia, 1940s to 1960s. Population and Development Review, 29, 215-254.

Jones, G.W. (1981). Malay marriage and divorce in Peninsular Malaysia: Three decades of change. Population and Development Review, 7(2), 255-278.

Jones, G.W. (1994). Marriage and Divorce in Islamic Southeast Asia, Singapore: Oxford University Press.

Jones, G.W. (1997). Modernization and divorce: contrasting trends in Islamic Southeast Asia and the West. Population and Development Review, 23(1), 95-114.

Kalmijn, M., \& Ann-Right Poortman (2006). His or her divorce? The gendered nature of divorce and its determinants, European Sociological Review, 22(2), 201-214.

Mohamad, M., \& Shuib, R. (2011). Marriage among the "urbanized" rural poor: return migrants in northwest Kelantan. In Gavin W. Jones, Terence H. Hull and Maznah Mohamad (eds), Changing Marriage Patterns in Southeast Asia: Economic and Socio-Cultural Dimensions (pp. 156-170). London: Routledge. 
Mohamad, M., \& Suratman, S. (2016). Marriage and divorce among Malays in Singapore: "nurture" rather than "nature" as key to building intact and resilient families. Lianhe Zaobao, 4 December.

National Population and Family Development Board. (2016). Report on Key Findings, Fifth Malaysian Population and Family Survey (MPFS-5, 2014), LPPKN: Kuala Lumpur. Retrieved from http://familyrepository. lppkn.gov.my/659/1/Report\%20on\%20Key\%20Findings\%20\%20 Fifth $\% 20$ Malaysian $\% 20$ Populationand $\% 20$ Family $\% 20$ Survey $\% 20$ $\% 28$ MPFS-5\%29\%202014.pdf

Norizan, A.G., Norris, I.N.H., Abdullah, B., Ahmad, M.F., Zulkifli, N.I., \& Hasan, M.R. (2017). Divorce trends among the Malay community in Perlis, Malaysia over a ten-year period (2006-2015). International Journal of Academic Research in Business and Social Science, 7(4), 269-283.

OECD. (2019). OECD Family Database. Retrieved from http://oecd.org/els/ family/database.htm

Rinaldo, R., Nisa, E.F., \& Nurmila, N. (2020). Divorce narratives and class inequalities in Indonesia. Paper presented at Conference on Emerging Dimensions of Marriage in Asia, Asia Research Institute, National University of Singapore, 19-20 November.

Rosenfeld, M.J. (2018). Who wants the breakup? Gender and breakup in heterosexual couples. In D.F. Alwin, D. Felmlee, and D. Kreager (eds), Social Networks and the Life Course: Integrating the Development of Human Lives and Social Relational Networks (pp. 221-243). Switzerland: Springer International Publishing.

Tan, P.C., \& Jones, G.W. (1990). Malay divorce in Peninsular Malaysia: the near-disappearance of an institution. Southeast Asian Journal of Social Science, 18(2), 85-114.

Tey, N.P. (2009) The changing marriage patterns among women in Peninsular Malaysia since 1970. In J. Ariffin (ed), Women in Development - Two Decades of Change. Kuala Lumpur: MPH Publisher. Tey, N.P. (2011). Understanding marriage and divorce trends in Peninsular Malaysia. In Gavin W. Jones, Terence H. Hull and Maznah Mohamad (eds), Changing Marriage Patterns in Southeast Asia: Economic and Socio-Cultural Dimensions (pp. 137-155). London: Routledge.

Tey, N.P. (forthcoming). Marriage trends and patterns in Sabah. In Tey Nai Peng, Lai Siow Li and Chan Kim Lian (eds), Population and Family in Sabah. Sabah: UMS Press. 